\title{
THE GRAMMATIZATION OF EMOTIONS ON FACEBOOK IN THE ELECTIONS TO THE PARLIAMENT OF CATALONIA 2017
}

\section{Gramatización de las emociones en Facebook en las elecciones al Parlament de Catalunya 2017}

\section{Òscar Coromina, Emili Prado and Adrián Padilla}

Nota: Este artículo se puede leer en español en:

http://www.elprofesionaldelainformacion.com/contenidos/2018/sep/05_esp.pdf

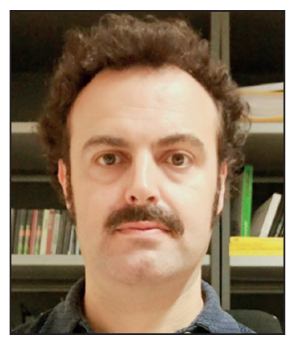

Òscar Coromina is an associate professor and researcher in the Department of Audiovisual Communication and Advertising of the Universitat Autònoma de Barcelona (UAB) where he has been a member of the teaching team since 2008. He has accumulated more than 15 years of experience in digital marketing. He is coordinator of the Master in Communication and Digital Marketing and member of Griss (Grup de Recerca en Imatge, So i Síntesi). His PhD thesis deals with the mediation on Twitter of political disputes. His research interests are digital culture in general, and social media and digital research methods in particular.

https://orcid.org/0000-0002-6306-4154

oscar.coromina@uab.cat

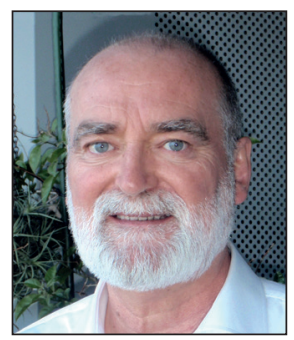

Emili Prado is a professor of Audiovisual Communication and Advertising at the Universitat Autònoma de Barcelona (UAB). He is director of Griss (Grup de Recerca en Imatge, So i Síntesi) and of Euromonitor, permanent observatory of television in Europe. He is the author of works on radio, television, and information and communication technologies.

https://orcid.org/0000-0003-4871-2472

emili.prado@uab.cat

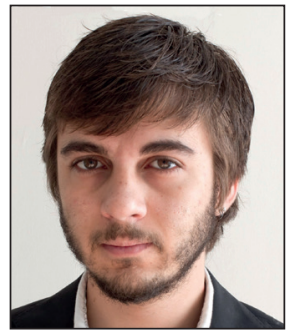

Adrián Padilla is a senior technician in support of research at the Department of Audiovisual Communication and Advertising of the Universitat Autònoma de Barcelona (UAB). He has a degree in Journalism from the $U A B$ and has completed a master's degree in Communication and Digital Marketing.

https://orcid.org/0000-0001-7668-1322

adrian.padilla@uab.cat

Universitat Autònoma de Barcelona Departament de Comunicació Audiovisual i Publicitat Campus de la UAB, Edifici I. 08193 Bellaterra (Barcelona), Spain

\begin{abstract}
This article proposes the analysis of reactions, emojis, and stickers of Facebook as a method to analyze the way in which the platform grammatizes the actions of the users and also the emotions invoked by the narratives that are deployed in the social network. To do this, we took, as a study case, the electoral campaign of the elections to the Parliament of Catalonia held on December $21^{\text {st }}, 2017$. Our analysis allows us to identify the emotions to which the narratives of the parties appealed, the main formats used during the campaign and their relationship with emotional response, and the possibilities available to users to convey the most visceral feelings.
\end{abstract}

\section{Keywords}

Political communication; Facebook; Social media; Elections; Grammatization; Emotions.

\section{Resumen}

Este artículo propone el análisis de reacciones, emojis y stickers de Facebook como método para analizar la forma en que la plataforma gramatiza las acciones de los usuarios y también las emociones que invocan las narrativas que se despliegan 
en dicha red social. Para ello, toma como caso de estudio la campaña electoral de las elecciones al Parlament de Catalunya celebradas el 21 de diciembre del 2017. Este análisis permite identificar las emociones a las que apelan las narrativas de los partidos, los principales formatos utilizados durante la campaña y su relación con las emociones, y las posibilidades de las que disponen los usuarios para vehicular los sentimientos más viscerales.

\section{Palabras clave}

Comunicación política; Facebook; Medios sociales; Elecciones; Gramatización; Emociones.

Coromina, Òscar; Prado, Emili; Padilla, Adrián (2018). "The grammatization of emotions on Facebook in the elections to the Parliament of Catalonia 2017". El profesional de la información, v. 27, n. 5, pp. 1004-1011.

https://doi.org/10.3145/epi.2018.sep.05

\section{The politics of emotions in the era of social platforms}

In recent years we have lived through several political elections in which emotions seem to have had an impact on the result, or at least on the design and execution of electoral campaigns. This has been pointed out by journalists, political analysts, and political leaders, among others, in the case of:

- elections to the presidency of the United States (Signer, 2015);

- referendum on the exit of the European Union held in the United Kingdom (Norman, 2017);

- Catalan conflict (Pérez-Oliva, 2017).

In all these cases emotional behavior is opposed to rational decision making, which raises an alert about the possible damage that this tendency can have on our society. However, by contrasting emotion and reason there is also the risk of establishing a false dilemma and obviate that among politicians and political scientists the management (and instrumentalization) of emotions has historically been an element of central interest (Calhoun, 2001). Although during the first half of the twentieth century dominant paradigms in the investigation of social movements diverted attention to the influence and affects in the development of collective action (Goodwin, 2018), today emotions refocus the interest of the academy as they motivate, are part of the rhetoric, shape the speeches, and allow sharing the objectives articulated by social and political movements (Jasper, 2011). Emotions also play a very important role in building collective identities. In the construction of these identities affinities have more weight than common interests. Affects favor solidarity among members of social movements creating bonds of trust, loyalty, and feelings (Goodwin; Jasper; Polletta, 2000).

This renewed interest in the role of emotions in politics coincides with the prominence that social platforms have acquired in electoral processes and collective actions. These platforms are especially useful for political organizations and their communication teams, and are used to:

- strengthen the links between political organizations and their electorate (Ward; Gibson, 2008; Túñez; Sixto-García, 2011);

- mobilize the bases (Castells, 2013);

- connect with the younger sectors of the electorate (Utz, 2009).
At the same time, social media platforms facilitate the participation of users in organizational aspects, creation of narratives, and dissemination of collective actions (Bennett, 2012). In social platforms the themes and interpretations that make up the stories are chosen, filtered, and disseminated in a process in which users and organizations collaborate, negotiate, or struggle to impose a certain story (Coromina, 2017). This process has many similarities with the constant negotiation model that has been used to describe relations between journalists and politicians (Casero-Ripollés, 2008). In this process, emotions act as a driving force, both in terms of defining the stories through which the narrative unfolds, and when it comes to forming and uniting the audiences that participate in the story (Papacharissi, 2014). In addition, in social networks the affinity between users is a particularly relevant factor in the propagation of the different narratives since there is a tendency to establish connections and share information with people of similar points of view and ideologies. This favors the appearance of personalized information environments that can be characterized as echo chambers or filter bubbles (Bakshy; Messing; Adamic, 2015; Freelon, 2017; Pariser, 2011).

Many of the mechanisms that operate within these practices are hidden from simple observation, but all the actions carried out by users generate metadata that, to a lesser or greater extent, are accessible through the interfaces that regulate the information and the format of what is published on the platforms. In the user interface of Facebook, for example, along with the content, the number of likes, comments, and shares stands out and becomes an influential element when generating interaction with content and other users (Shifman, 2014). The application interface (API) regulates the exchange of information between Facebook and the applications that articulate the economic and social apparatus of the platform (Gerlitz; Helmond, 2013). Allows the automated, massive, and structured collection of user data. The analysis of the digital traces left by the activity of users has a great utility in many areas including the entertainment industry, marketing, political propaganda, and scientific research. Without going any further, the data used to develop this article have been obtained through the Facebook API. Indicators such as the number of likes, comments, and shares helped us to understand the way in which users interact with content and have allowed us to identify the affective bonds that can be established with content, themes, products, brands, political parties, etc. (Mollen; 
Wilson, 2010). For these reasons, appealing to feelings is a persuasive communication strategy that can generate interesting returns during electoral contests (Abejón-Mendoza; Mayoral-Sánchez, 2017).

\section{Facebook and the grammatization of emotions}

Facebook is the most popular of social networks, with more than 2 billion users worldwide (Facebook, 2018). Due to its characteristics, we can define it as a social network since it fulfills the requirement of being an application that allows its users to establish connections between themselves and to manage a personal profile (Ellison; Boyd, 2013). Users publish information on their wall, a space in which a biographical narrative is displayed and in which they combine the presentation of impressions, memories, and emotions with self-promotion (Van-Dijck, 2013). The wall and the possibility of interacting with content is a feature shared with Facebook's pages and groups, which are spaces created to promote the generation of communities around companies, brands, public figures, and interests (Sixto-García, 2017). These entities -pages and groups- are usually managed by a small group of administrators who create the content, also referred to as posts. In addition, members of these communities also participate in the building and propagation of narratives through reactions, comments, and shares. In addition, comments allow users to extend, complete, debate, or question the published information.

Emotional reactions demand greater reflection from the user than a simple like

We have to consider that these indicators are more than popularity metrics, they all have important consequences in the operation of the platform. Likes, comments, and shares regulate the system of notifications and impressions on the wall. For example, in February 2016 Facebook added new possible responses to a post; reproduced in Figure 1, they allowed users to give an emotional response to content, and also offered them the opportunity to be more precise with the type of answer they wanted to give in each situation. In addition to the classic like, they added the possibility of showing love (love), laughter (haha), surprise (wow), sadness (sad), and anger (angry). Along with the implementation of these new elements came an update of the publication algorithm, and although the exact operating parameters of the Facebook algorithm are opaque, it was clear that a change to the algorithm gave more visibility to content with emotional reactions. Assuming that emotional reactions require greater reflection from users, in this study greater weight was given to those posts that received the most emotions in response (Stewart, 2017).

At this point it is necessary to introduce the concept of "grammars of action", introduced by Agre (1994) to describe how software (then) and social platforms (now) channel communication, publication, and interaction with methods by which different actions are constructed. The grammatization of the action entails two important consequences:
- the interaction of the users is structured from a limited number of formal operations and this formalization allows them to be integrated into a database in a logical and organized manner (Gerlitz; Rieder, 2018). In the present case, Facebook grammatizes the emotional response from the 6 reactions available to users. It is interesting to note that the selection of possible states has the result of making certain emotions visible and relegating others to a second plane;

- this reaction is counted and displayed in the user interface allowing the user to anticipate details about the type of content that has been published. At the same time, these metadata are also accessible through the API.

Although grammatization and grammaticalization are often used as synonyms, here we accept the distinction that considers that the first fixes, refines, normalizes, and stabilizes, while the second is a process of dynamic coding, in continuous readjustment and change (Girón-Alconchel, 2005).

\section{Case study}

This article uses as a case study the elections to the Generalitat de Catalunya (Catalan Government) on December 21, 2017 to analyze and understand how social networks contributed to the emotionalization of politics from the evolution of the electoral campaign on the social platform Facebook by political parties that obtained representation in the Parliament of Catalonia. The election transpired under exceptional circumstances: suspended self-government institutions, imprisoned candidates, and candidates who had fled the country-all of which favored the deployment of narratives that appealed to emotions and polarization.

\section{Objective and research questions}

This research approaches grammatized reactions on the $\mathrm{Fa}$ cebook platform to find out how electoral campaign strategies appeal to emotions in the unfolding of their narratives. Likewise, we are interested in understanding how the content format influences the emotional response of users and exploring to what extent the action grammars of Facebook leave room for more visceral reactions of criticism and dissension. To achieve these objectives we formulated the following research questions:

- What emotions are invoked from the deployed narratives of the political parties during the campaign?

- What format of content favors interaction in an emotional way?

- What tools does Facebook offer for users to channel their most intense emotions?

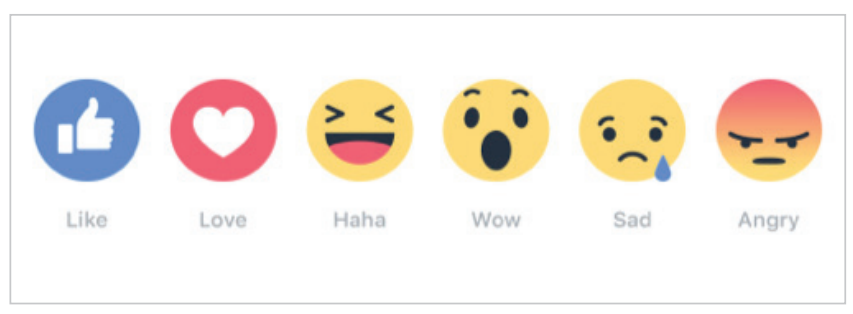

Figure 1. Facebook reactions Source: Facebook Inc. 


\section{Methods}

The methods used in this research are aligned with the proposal of Rogers (2013) to study social and cultural phenomena by repurposing information, methods, and processes of digital platforms and other technological applications. For this we have used Netvizz, a program specifically designed to investigate with an approach that allows the extraction and analysis of data from Facebook pages through an application interface (API) (Rieder, 2013). Through this method we have obtained a collection of data constituted by 1,302 posts published in the pages of the 7 political parties that finally obtained representation in the Parliament of Catalonia, between October 27 $7^{\text {th }}, 2017$, the date in which elections were called via article 155, and the day of the vote, December $21^{\text {st }}, 2017$. Along with the posts, 93,933 comments and 461,305 reactions were captured, as reflected in table 1.

\section{Like is the preferred reaction when inte- racting with content}

One of the candidacies analyzed -Junts per Catalunya- created their page on November $22^{\text {nd }}, 2017$, because the group was formed after the elections were called. We approached this peculiarity as a consequence of the exceptional circumstances that surrounded the celebration of the elections, and for this reason we renounce comparisons between this party and the others in terms of success and effectiveness. In addition, the engagement indicators are directly related to the number of followers of the Facebook pages and limiting the dates to a common rank among all the parties would not have solved the problem: Junts per Catalunya had less time to articulate their presence in Facebook and win a sufficient number of followers. Instead we look at the type of reactions to characterize the narratives of each party and analyze them from percentages. Additionally, data mining techniques are used to analyze the presence of stickers and emojis in the comments.

\section{Reactions to publications}

In a first approximation to the extracted data, we observe that like was the preferred reaction by the users to interact with content. As shown in Graph 1, in all the analyzed cases, they exceeded $80 \%$ of the total of the registered reactions. Likes made up most of the reactions to the posts of the parties. Like should be interpreted as an option to show adhesion and acceptance of content that does not necessarily entail an emotional component and, therefore, is more difficult to analyze in emotional terms. We also observed significant differences in relation to the weight of emotional reactions in each of the political parties. This data suggests that some parties carried out communication strategies more oriented to generate emotional responses than others.

Video and images are the dominant formats, what corroborates the audiovisualization of Facebook

We gave the emotional reactions (love, wow, haha, sad and angry) on Facebook a greater significance value, because the action of choosing one requires the user to perform a reflection exercise. Their choice reveals more precision in the state of mind. As a consequence, we eliminated likes from the analyzed set, and counted those which were the most used reactions. Figure 2 shows the distribution of reactions across all the posts analyzed. We observe the love reaction was the most used reaction in the global calculation, exceeding $70 \%$ over the total of recorded reactions. This data suggests a high degree of concordance between the followers of the parties on Facebook, which delves into the significance of unconditional adhesion that is already expressed in the predominance of likes.

The detailed analysis of the reactions by party shows a very unequal distribution of the feelings aroused by the publications of each political formation. As shown in Table 2, PP and PSC were well below the average in reactions such as love, while Ciudadanos and Junts per Catalunya capitalized on this feeling, reaching more than $90 \%$ of the total reactions. On the opposite side, $P P$ and $P S C$ are the ones that

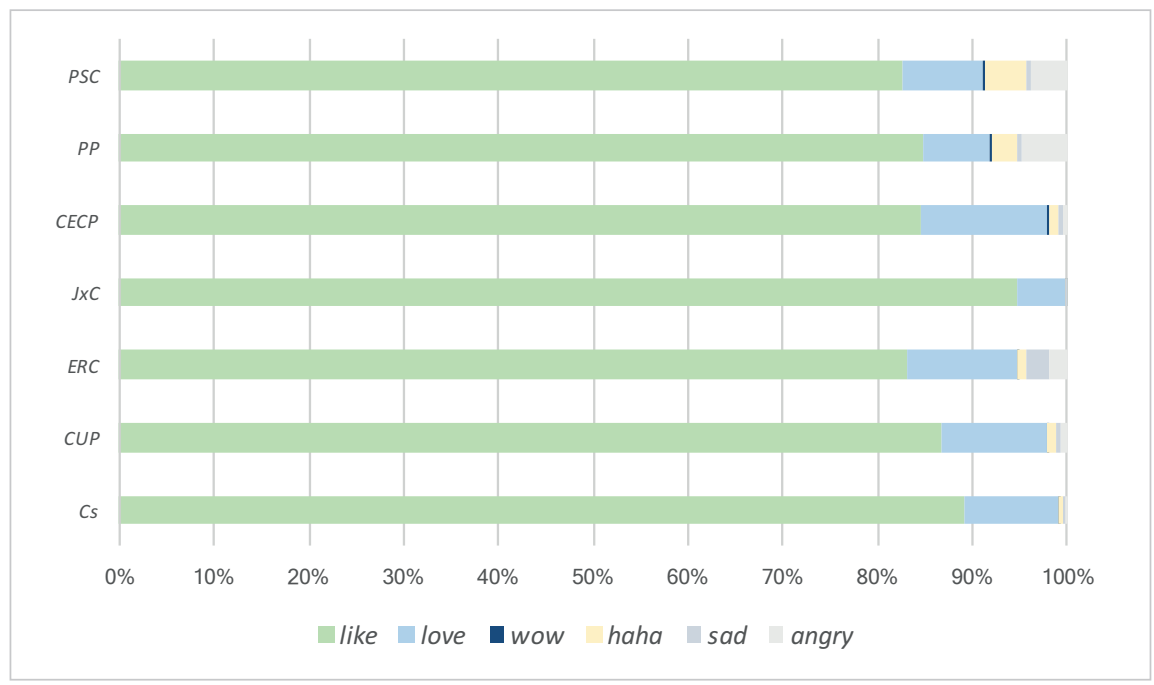

Graphic 1. Share of likes and emotional reactions by party 


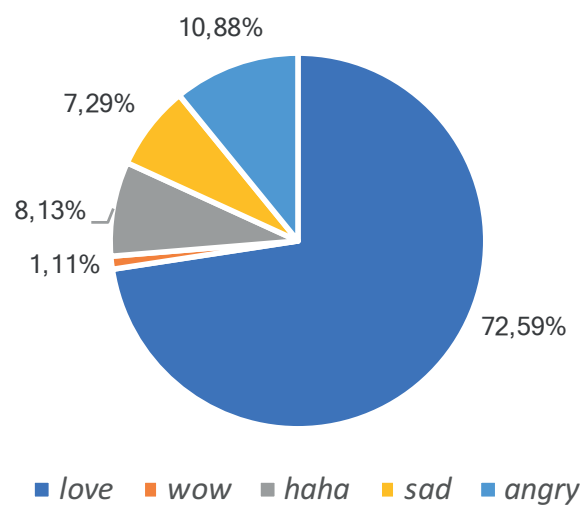

Graph 2. Percentage of reactions use
Table 2. Distribution of reactions per party (\%)

\begin{tabular}{|l|r|r|r|r|r|}
\hline \multicolumn{1}{|c|}{ Party* } & Love & Wow & Haha & Sad & Angry \\
\hline CS & 91.19 & 0.91 & 3.72 & 1.55 & 2.64 \\
\hline CUP & 82.73 & 0.88 & 7.25 & 3.38 & 5.76 \\
\hline ERC & 68.44 & 0.84 & 4.62 & 14.27 & 11.83 \\
\hline JXC & 94.48 & 0.22 & 1.08 & 3.74 & 0.47 \\
\hline CECP & 85.23 & 2.93 & 5.75 & 3.15 & 2.93 \\
\hline PP & 45.65 & 1.76 & 17.91 & 2.47 & 32.21 \\
\hline PSC & 48.80 & 1.64 & 23.92 & 3.54 & 22.09 \\
\hline Total & 72.59 & 1.11 & 8.13 & 7.29 & 10.88 \\
\hline
\end{tabular}

* Cs: Ciudadanos, CUP: Candidatura d'Unitat Popular, ERC: Esquerra Republicana de Catalunya, JxC: Junts per Catalunya, CECP: Catalunya en Comú-Podem, PP: Partido Popular, PSC: Partit Socialista de Catalunya. exceeded the average of reactions considered negative, such as angry, where they reach $32 \%$ and $22 \%$ respectively, on an average that is just over $10 \%$, if we consider the data of all the parties. Likewise, ERC shows a particularly high percentage of sad and angry that we can relate to the imprisonment of independentist political leaders in their narrative.

Using the categorization of formats established by Facebook itself, table 3 shows the way users distributed these reactions according to the format of the content published by the parties. The data has been normalized to percentages to make it easier to read. The format that provoked the most reactions was video, accumulating more than $74 \%$ of the emotional reactions of the users, followed by photos, with $21 \%$.

Regarding the type of publication, video and images are also confirmed as dominant formats, what corroborates the audiovisualization of Facebook, a trend whose birth was previously detected by Coromina and Prado (2013). If we compare the two columns on the right (Total reactions and Total publications) we observe how video format was the most used by the parties to publish (54\%), and the one that proportionally generated more emotional reactions in the users. Results show that the communication teams of the parties clearly tried spreading their messages in the form of videos and photographs and that this practice obtained the prize of greater emotional interaction.

\section{Emojis and stickers}

The use of standardized graphic elements, such as emojis and stickers to comment on party publications, was much less frequent than interaction in the form of reaction, as shown

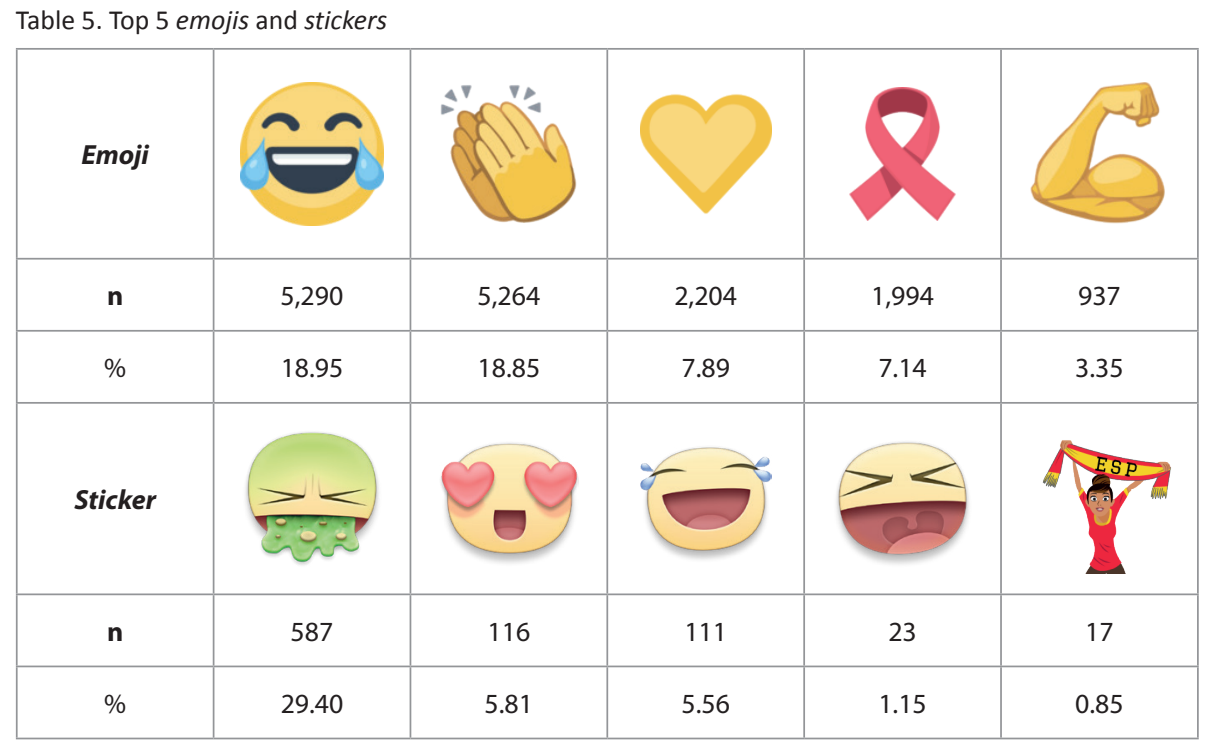


In the same way, we must bear in mind that the use of emojis is linked to certain practices. For example, it is common for users to paste the same icon several times in the same comment to emphasize their reaction.

Table 5 shows the 5 emojis and the 5 stickers most recurrent in the comments to the publications of the political parties. It is interesting to note that the use of emojis was concentrated in a smaller number of options since the 5 ideograms of the top 5 represent more than $50 \%$ of the total, while the use of stickers was much more atomized. If we look at the meaning of the icons, we can distinguish that the emojis of the top 5 can be associated with positive reactions. In the case of stickers, the most dominant visceral rejection was expressed with the vomit icon, which represented almost $30 \%$ of the stickers published.

In a more detailed analysis of the most used emojis in each of the party walls (Table 6), we can see how the expression of positive feelings remained dominant. However, emojis were also used to show rejection as clearly demonstrated by the presence of the poop emoji in the case of the Partido Popular and the Partit Socialista de Catalunya or the middle finger in the CUP. Another noteworthy aspect is the fact that the use of emojis to express emotions coexisted with an ideogrammatic use in which they served to express concepts or simple messages; this practice served to reinforce and reaffirm aspects related to the identity of the parties. Such would be the case of the use of the orange in the page of Ciudadanos, the fist in those of the CUP and CECP, the ties in ERC and $J \times C$, the parking $\mathrm{P}$ in the $P P$ or the rose in the $P S C$. We must also make special mention of the presence of the ribbon on the page of $C s$ that was associated with a protest action by users related to the independence movement.

Table 7 shows the use of stickers on each page of the parties. We observe that puke was a recurring sticker to show rejection, leading in practically all usage rankings. Stickers associated with membership also had a presence on all pages and, to a lesser extent, those related to laughter. In order to identify possible relationships between the use of these two formats with certain emotional reactions over others we calculated the correlation between the 6 reaction modes and the use of stickers and emojis on the pages

Table 8. Correlation between reactions, stickers, and emojis

\begin{tabular}{|l|c|c|c|c|c|c|}
\hline & Like & Love & Wow & Haha & Sad & Angry \\
\hline Stickers & 0.26 & 0.24 & 0.28 & 0.59 & 0.54 & 0.83 \\
\hline Emojis & 0.84 & 0.59 & 0.04 & -0.24 & 0.56 & 0.13 \\
\hline
\end{tabular}

of political parties. As shown in table 8, there was a strong correlation between the use of stickers and the angry reaction and between the use of emoji and the like reaction. Moderate correlations were also detected between the use of stickers and the haha and sad reactions and between the use of emojis and the love and sad reactions.

The use of emojis is linked to positive reactions, while stickers channel the negative ones

\section{Conclusions}

The analysis of the reactions to the posts in the pages of the political parties that relate to the elections to the Parliament of Catalonia has made it possible to verify how the campaign strategies opt for narratives that appeal primarily to positive feelings and adhesion. In addition, we have observed that some parties are more effective than others in achieving this goal and also that the exceptional circumstances surrounding the holding of these elections (imprisoned candidates and suspension of self-government of the autonomous community) led, in the case of Esquerra Republicana de Catalunya (ERC), the display of stories that invoke emotions of anger and sadness. Likewise, we have detected situations in which there was a divergence between the 
emotions to which the posts appealed and those that ultimately provoked them. The most obvious cases concern the $P S C$ and the $P P$, but it was a circumstance that, to a lesser extent, was reproduced by the rest of the parties. This discrepancy is an aspect that we consider of special relevance and we believe that future research should be conducted to see to what extent it can be a useful indicator to evaluate the success of communication strategies in electoral campaigns. Beyond helping us analyze our case study, the analysis of reactions is an effective method to analyze the emotions that are invoked in the narratives that are deployed on Facebook.

The format that provoked the most reactions was video, accumulating more than $74 \%$ of the emotional reactions of users

The results also make it clear that video was the content format that most effectively generated emotional reactions, followed by photography. In this sense, we consider particularly revealing the fact that the political parties bet decisively on the audiovisual content when it came to disseminating their messages, especially when considering the production requires greater planning and resources. Everything seems to indicate that the use of video can be related to the promise of a greater prize in the form of emotional interaction. To what extent Facebook's algorithms intervene in this equation is an aspect that we cannot respond with the methodology used, but it seems prudent to take it into consideration.

The introduction of reactions by Facebook has followed a process of grammatization of emotions within the landscape of political correctness. However, the analysis of emojis and stickers has allowed us to show that these resources are used to manifest rejection, criticism, and boycott in a more visceral way, following a grammaticalization process at the service of free emotional interaction. Actually -as we said before-, although grammatization and grammaticalization are often used synonymously, here we recognize a distinction that considers the first, grammatization, as fix, debug, normalize, and stabilize; while the second is a dynamic coding process, in continuous readjustment and change (Girón-Alconchel, 2005). In the case of stickers, it is particularly evident. As shown on the one hand by the recurrence of the puke illustration and on the other the strong correlation between the number of anger reactions and the use of stickers. With regards to emojis, it is worth noting that in addition to expressing dissension, in their ideogrammatic use they play a very significant role in the representation of the identity of the parties. In this sense, the strong correlation between the use of emojis and the number of likes -and the moderate correlation with the number of loves- suggests that ideograms constitute a more complex form of expressing adhesion.

\section{References}

Abejón-Mendoza, Paloma; Mayoral-Sánchez, Javier (2017). "Persuasión a través de Facebook de los candidatos en las elecciones generales de 2016 en España". El profesional de la información, v. 26, n. 5, pp. 928-936.

https://doi.org/10.3145/epi.2017.sep.14

Agre, Philip E. (1994). "Surveillance and capture: Two models of privacy". The information society, v. 10, n. 2, pp. 101-127. https://doi.org/10.1080/01972243.1994.9960162

Bakshy, Ethan; Messing, Solomon; Adamic, Lada (2015). "Exposure to ideologically diverse news and opinion on Facebook". Science, v. 348, n. 6239, pp. 1130-1132. http://education.biu.ac.il/files/education/shared/science2015-bakshy-1130-2.pdf https://doi.org/10.1126/science.aaa1160

Bennett, W. Lance (2012). "The logic of connective action : Digital media and the personalization of contentious polítics". Information, communication \& society, v. 15, n. 5, pp. 739-768.

http://ccce.com.washington.edu/about/assets/2012iCSLCA-Bennett\&Segerberg-LogicofConnectiveAction.pdf https://doi.org/10.1080/1369118X.2012.670661

Calhoun, Craig (2001). "Putting emotions in their place". In: Goodwin, Jeff; Jasper, James M.; Polletta, Francesca (eds.). Passionate politics. University of Chicago Press, pp. 45-57. ISBN: 9780226303987 https://doi.org/10.7208/chicago/9780226304007.003.0003

Casero-Ripollés, Andreu (2008). “Modelos de relación entre periodistas y políticos : La perspectiva de la negociación constante". Estudios sobre el mensaje periodístico, v. 14, pp. 111-128.

http://revistas.ucm.es/index.php/ESMP/article/view/ ESMP0808110111A

Castells, Manuel (2013). Communication power. Oxford: Oxford University Press. ISBN: 9780199681938

Coromina, Òscar (2017). "The struggle for the story in political disputes. The case of the $9 \mathrm{~N}$ participation process". El profesional de la información, v. 26, n. 5, pp. 884-893. https://doi.org/10.3145/epi.2017.sep.10

Coromina, Òscar; Prado, Emili (2013). "La Diada a Facebook: Anàlisi de l'activitat dels usuaris a la pàgina de l'Assemblea Nacional Catalana". In: Marqués, Joaquim (coord.). Il Congrés de comunicació política de Catalunya. Acciep, Barcelona, pp 12-29.

http://www.oscarcoromina.com/wp-content/uploads/ prado-coromina-anc.pdf

Ellison, Nicole B.; Boyd, Danah M. (2013). "Sociality through social network sites". In: Dutton, W. H. (ed.). The Oxford handbook of internet studies. Oxford: Oxford University Press, pp. 151-172.

https://www.danah.org/papers/2013/SocialityThruSNSpreprint.pdf

Facebook (2018). Facebook newsroom. https://es.newsroom.fb.com/company-info

Freelon, Deen (2017). "Personalized information environments and their potential consequences for disinformation". In: Understanding and addressing the disinformation ecosystem. Annenberg School for Communication, pp. 38-44. 
https://firstdraftnews.org/wp-content/uploads/2018/03/ The-Disinformation-Ecosystem-20180207-v3.pdf?x17007

Gerlitz, Carolin; Helmond, Anne (2013). "The like economy: Social buttons and the data-intensive web". New media \& society, v. 15 , n. 8 , pp. 1348-1365.

https://doi.org/10.1177/1461444812472322

Gerlitz, Carolin; Rieder, Bernhard (2018). "Tweets are not created equal: Investigating Twitter's client ecosystem". International journal of communication, n. 12, pp. 528-547. http://ijoc.org/index.php/ijoc/article/viewFile/5974/2252

Girón-Alconchel, José-Luís (2005). “Gramaticalización y gramatización: los futuros analíticos". In: Santos-Ríos, Luis; Borrego-Nieto, Julio; García-Santos, Juan-Felipe; Gómez-Asencio, José J.; Prieto-de-los-Mozos, Emilio (eds.). Palabras, norma, discurso en memoria de Lázaro Carreter. Salamanca: Ediciones Universidad de Salamanca, pp. 581-592. ISBN: 84 78004939

Goodwin, Jeff (2018). "The libidinal constitution of a highrisk social movement: Affectual ties and solidarity in the huk rebellion, 1946 to 1954". American sociological review, v. 62, n. 1, pp. 53-69.

http://www.sscnet.ucla.edu/polisci/faculty/chwe/ps269/ goodwin.pdf

Goodwin, Jeff; Jasper, James M.; Polletta, Francesca (2000). "The return of the repressed: The fall and rise of emotions in social movement theory". Mobilization: An international journal, v. 5, n. 1, pp. 66-83.

http://www.socsci.uci.edu/ polletta/Articles\%20and\%20 Book\%20Chapter_files/Return_of_repressed.pdf

Jasper, Jeff (2011). "Emotions and social movements: Twenty years of theory and research". Annual review of sociology, v. 37, n. 1 , pp. $285-303$.

https://doi.org/10.1146/annurev-soc-081309-150015

Mollen, Anne; Wilson Hugh (2010). “Engagement, telepresence and interactivity in online consumer experience: Reconciling scholastic and managerial perspectives". Journal of business research, v. 63, n. 9-10, pp. 919-925.

https://doi.org/10.1016/j.jbusres.2009.05.014

Norman, Laurence (2017). "EU warns emotions getting out of hand on Brexit". The Wall Street Journal, May $4^{\text {th }}$.

https://www.wsj.com/articles/eu-warns-emotions-gettingout-of-hand-on-brexit-1493917708

Papacharissi, Zizi (2014). Affective publics. Oxford University Press. ISBN: 9780199999736

https://doi.org/10.1093/acprof:oso/9780199999736.001.0001

Pariser, Eli (2011). The filter bubble: What the Internet is hi- ding from you. New York: Viking/Penguin Press. ISBN: 9780 241954522

Pérez-Oliva, Milagros (2017). "La importancia de gestionar las emociones". El país, 5 octubre.

https://elpais.com/elpais/2017/10/04/opinion/1507137825_627800. html

Rieder, Bernhard (2013). "Studying Facebook via data extraction". In: Proceedings of the $5^{\text {th }}$ Annual ACM Web science conference. WebSci'13 (Paris, May 2-4), pp. 346-355. ISBN: 9781450318891

https://doi.org/10.1145/2464464.2464475

Rogers, Richard (2013). Digital methods. Cambridge: MIT Press. ISBN: 9780262018838

Shifman, Limor (2014). Memes in digital culture. Cambridge: Mit Press. ISBN: 9780262525435

Signer, Michael (2015). "Trump and the dangers of passionate politics". The Atlantic, Aug. $22^{\text {nd }}$.

https://www.theatlantic.com/politics/archive/2015/08/ispassion-meant-for-politics/402457

Sixto-García, José (2017). "Storytelling de las organizaciones en Facebook: ¿̇Interactividad o presencia corporativa?". Hipertext.net, n. 15, p. 10-16.

https://doi.org/10.2436/20.8050.01.41

Stewart, Rebecca (2017). "Facebook tweaks its algorithm to give more prominence to posts with reactions". Busines insider, Feb. $28^{\text {th }}$.

http://www.businessinsider.com/facebook-tweaks-algorithmto-give-more-value-to-posts-with-reactions-2017-2

Túñez, Miguel; Sixto-García, José (2011). “Redes sociales, política y compromiso 2.0: La comunicación de los diputados españoles en Facebook". Revista latina de comunicación social, n. 66, pp. 1-25.

https://doi.org/10.4185/RLCS-66-2011-930-210-246

Utz, Sonja (2009). "The (potential) benefits of campaigning via social network sites". Journal of computer-mediated communication, v. 14, n. 2, pp. 221-243.

https://doi.org/10.1111/j.1083-6101.2009.01438.x

Van-Dijck, José (2013). "'You have one identity': Performing the self on Facebook and LinkedIn". Media, culture and society, v. 35, n. 2, pp. 199-215.

https://doi.org/10.1177/0163443712468605

Ward, Stephen; Gibson, Rachel (2008). "European political organizations and the Internet". In: Chadwick, Andrew; Howard, Philip N. (ed.). Routledge handbook of internet politics. Routledge, pp. 25-39. ISBN: 9780415429146 https://doi.org/10.4324/9780203962541.ch3

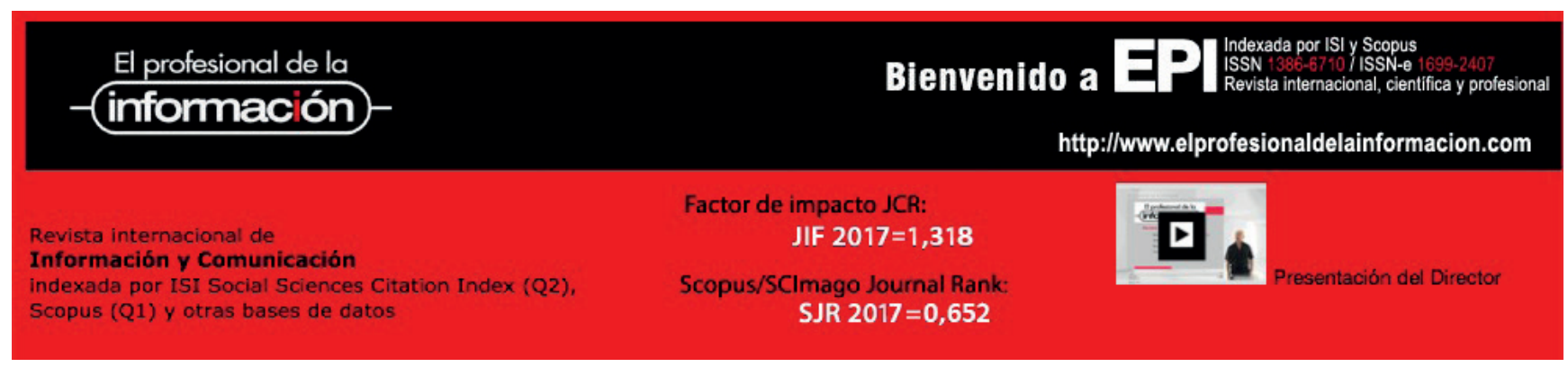


(2) 2,74 बा $(1-x)$

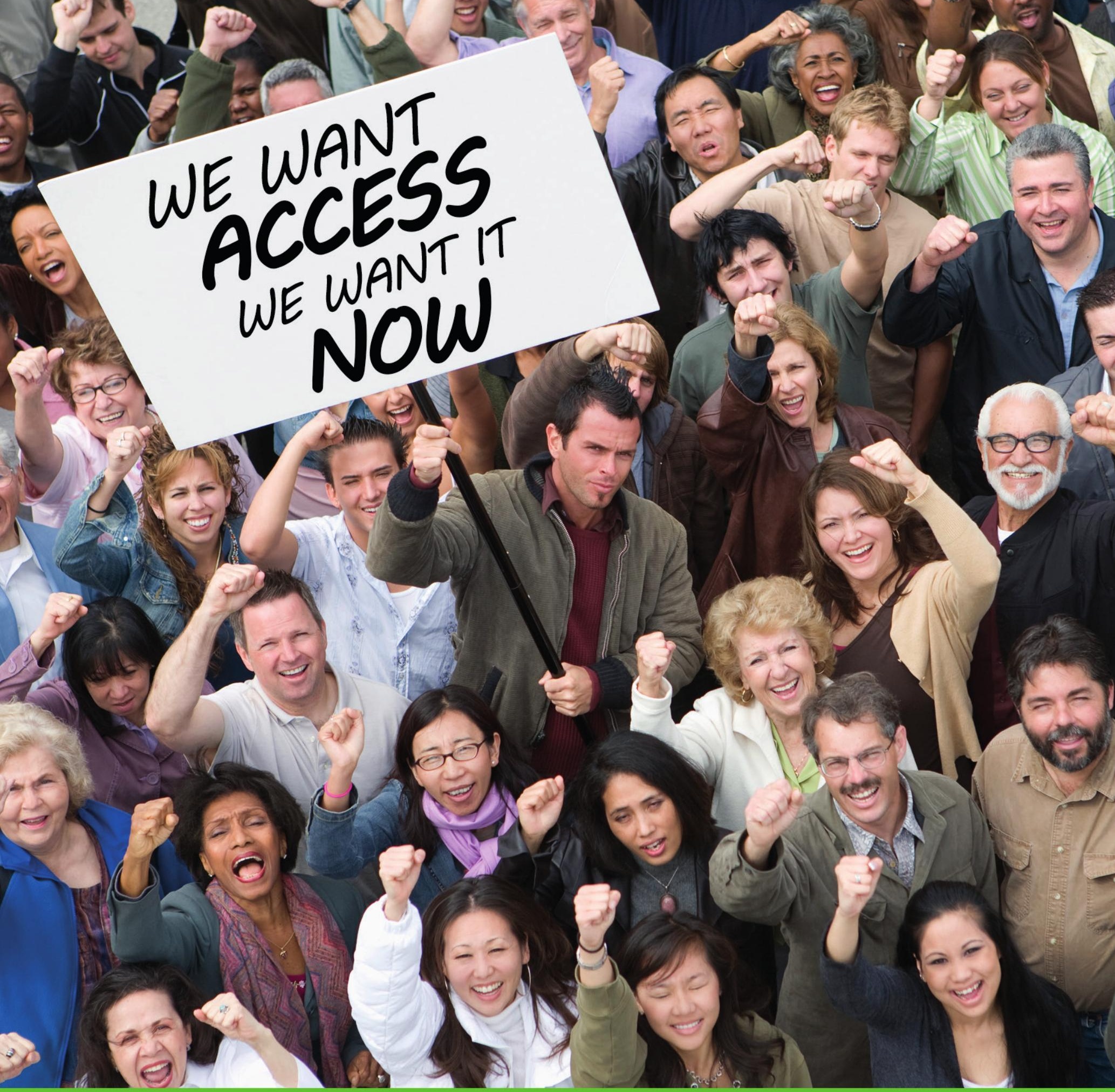

20 años diseñando

y gestionando información

MASmedios apoya la Declaracion de Lyon del 2014 que

propugna el derecho de las personas a acceder a la información. masmedios

www.masmedios.com 